\title{
Article \\ Experiments with Pyrotechnic Compositions Based on a Mathematical Model: Part II Pyrotechnic Compositions Producing an Acoustic Effect with Optimum Properties
}

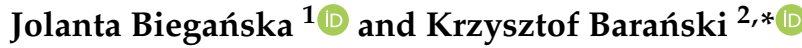

check for updates

Citation: Biegańska, J.; Barański, K Experiments with Pyrotechnic Compositions Based on a Mathematical Model: Part II Pyrotechnic Compositions Producing an Acoustic Effect with Optimum Properties. Energies 2022, 15, 794. https://doi.org/10.3390/en15030794

Academic Editor: Léo Courty

Received: 6 December 2021

Accepted: 17 January 2022

Published: 22 January 2022

Publisher's Note: MDPI stays neutral with regard to jurisdictional claims in published maps and institutional affiliations.

Copyright: (C) 2022 by the authors. Licensee MDPI, Basel, Switzerland. This article is an open access article distributed under the terms and conditions of the Creative Commons Attribution (CC BY) license (https:// creativecommons.org/licenses/by/ $4.0 /$ )
1 Department of Hydrogen Energy, Faculty of Energy Fuels, AGH University of Science and Technology, Aleja Adama Mickiewicza 30, 30-059 Kraków, Poland; biega@agh.edu.pl

2 Department of Mining Engineering and Work Safety, Faculty of Civil Engineering and Resource Management, AGH University of Science and Technology, Aleja Adama Mickiewicza 30, 30-059 Kraków, Poland

* Correspondence: baranski@agh.edu.pl

\begin{abstract}
The article presents a method of evaluating pyrotechnic compositions producing an acoustic effect. The aforementioned pyrotechnic compositions are used in firecrackers to simulate a cannon shot. Optimum compositions that were selected (Part I Evaluation of the applicability of mathematical models in developing pyrotechnic compositions producing an acoustic effect) for testing were evaluated for their explosive and physicochemical properties. The following methods were used to evaluate suitability: measurement of the sound intensity level, the burning rate, and sensitivity to mechanical stimuli-friction and flash fire temperature. In addition, a test concerning the change in the properties of pyrotechnic compositions during storage was also performed.
\end{abstract}

Keywords: pyrotechnic compositions; firecrackers; explosive properties; physicochemical changes

\section{Introduction}

Pyrotechnic compositions are divided according to the special effects they produce when ignited, e.g., flash, photoflash, band, smoke, simulation, flare, and ignition [1,2]. One of the most important requirements for pyrotechnic compositions is to achieve the maximum effect characteristic for a given type of pyrotechnic substance resulting from its application during combustion.

In addition to producing a special effect, the pyrotechnic composition should be characterized by [1-8]:

- $\quad$ Burning at a steady, defined rate.

- $\quad$ Physical and chemical stability during storage.

- $\quad$ Low sensitivity to mechanical stimuli.

- No production of toxic substances during burning.

- $\quad$ Easy production technology.

- $\quad$ Easily available and inexpensive ingredients.

Therefore, due to their different applications, the approval of pyrotechnic compositions for use requires tests to confirm suitability for use. These tests are common to many compositions but are also specific to particular products. For example, the group of parameters describing the physicochemical durability of compositions includes hygroscopicity [9], changes in the physicochemical properties of the tested substance (assumed as physicochemical durability parameters) before and after accelerated aging under conditions of variable temperature cycles [10], and alkali metal content in the composition [11-13].

A noise assessment is required for fireworks and combinations, firecrackers, Roman candle, butterflies and spinners. This parameter is measured by determining the sound pressure level, which corresponds to a value expressed in decibels [14,15]:

- $\quad$ The hearing threshold is $20 \mu \mathrm{Pa}=0 \mathrm{~dB}$. 
- $\quad$ Conversation is $20 \mathrm{mPa}=60 \mathrm{~dB}$.

- $\quad$ An artillery shot is $20 \mathrm{hPa}=160 \mathrm{~dB}$.

The purpose of firecrackers containing pyrotechnic compositions producing an acoustic effect is to simulate a cannon shot, i.e., to produce a cloud of smoke and to make a sound of high intensity as a result of combustion and rupture of the casing (paper body) in which the composition is placed.

For this type of pyrotechnic products, due to the application (military purposes), there is no generally available description of tests in the literature. Therefore, it has been assumed [16] that two groups of tests will be determined for the developed optimum composition:

1. For safety reasons.

2. Taking into account physical and chemical stability.

The objective of this paper is to demonstrate how firecracker testing is performed to measure safety properties and performance properties.

\section{Determination of the Optimum Compositions}

On the basis of the adopted mathematical model and the research included in the article entitled "Part I Evaluation of the Applicability of Mathematical Models in Developing Pyrotechnic Compositions Producing an Acoustic Effect, "pyrotechnic compositions with optimum parameters were selected. Friction sensitivity and burning rate were assessed and illustrated graphically. The percentage composition of the "reference composition" is shown in Table 1.

Table 1. The percentage content of components of optimum pyrotechnic compositions from the M-0 reference composition.

\begin{tabular}{cccc}
\hline \multirow{2}{*}{ Designation } & \multicolumn{3}{c}{ Content of Individual Components (\%) } \\
\cline { 2 - 4 } & $\mathbf{B a}\left(\mathrm{NO}_{3}\right)_{\mathbf{2}}$ & $\mathbf{P A M}^{*}$ & $\mathrm{~S}$ \\
\hline $\mathrm{M}-0$ & 64 & 18 & 18 \\
\hline
\end{tabular}

* An alloy with 50\% magnesium and 50\% aluminum called "magnalium" (PAM) in the form of a powder.

The following percentages of the components of the optimum composition were the basis for further study (Tables 2 and 3):

Table 2. The percentage content of components of optimum pyrotechnic compositions from the M-1 group obtained using mathematical modeling.

\begin{tabular}{ccccc}
\hline \multirow{2}{*}{ Designation } & \multicolumn{5}{c}{ Content of Individual Components (\%) } \\
\cline { 2 - 5 } & $\mathbf{K C l O}_{\mathbf{4}}$ & $\mathbf{F e}_{\mathbf{2}} \mathbf{O}_{\mathbf{3}}$ & $\mathbf{A l}$ & $\mathbf{S}$ \\
\hline $1 \mathrm{~A}$ & 38 & 19 & 28 & 15 \\
\hline $1 \mathrm{~B}$ & 42 & 13 & 30 & 15 \\
\hline $1 \mathrm{C}$ & 38 & 15 & 32 & 15 \\
\hline $2 \mathrm{~A}$ & 30 & 25 & 20 & 25 \\
\hline $2 \mathrm{~B}$ & 36 & 17 & 22 & 25 \\
\hline $2 \mathrm{C}$ & 35 & 14 & 26 & 25 \\
\hline $3 \mathrm{~A}$ & 34 & 5 & 26 & 35 \\
\hline $3 \mathrm{~B}$ & 35 & 15 & 15 & 35 \\
\hline $3 \mathrm{C}$ & 28 & 10 & 27 & 35 \\
\hline
\end{tabular}


Table 3. The percentage content of components of optimum pyrotechnic compositions from the M-2 group obtained using mathematical modeling.

\begin{tabular}{ccccc}
\hline \multirow{2}{*}{ Designation } & \multicolumn{4}{c}{ Content of Individual Components (\%) } \\
\cline { 2 - 5 } & $\mathbf{K C l O}_{\mathbf{4}}$ & $\mathbf{F e}_{\mathbf{2}} \mathbf{O}_{\mathbf{3}}$ & $\mathbf{P A M}$ & $\mathbf{S}$ \\
\hline $4 \mathrm{~A}$ & 36 & 18 & 26 & 20 \\
\hline $4 \mathrm{~B}$ & 35 & 18 & 27 & 20 \\
\hline $4 \mathrm{C}$ & 39 & 14 & 27 & 20 \\
\hline $5 \mathrm{~A}$ & 35 & 20 & 20 & 25 \\
\hline $5 \mathrm{~B}$ & 37 & 17 & 21 & 25 \\
\hline $5 \mathrm{C}$ & 38 & 15 & 22 & 25 \\
\hline $6 \mathrm{~A}$ & 30 & 20 & 20 & 30 \\
\hline $6 \mathrm{~B}$ & 37 & 13 & 20 & 30 \\
\hline $6 \mathrm{C}$ & 29 & 18 & 23 & 30 \\
\hline
\end{tabular}

It has been assumed that the primary criterion for evaluating a composition that produces an optimum acoustic effect is its loudness. This parameter was measured using the method described in Section 3.5.

The results obtained were compared with the reference composition (graphical presentation in the form of peaks).

Prospective mixtures were selected from each group, taking the sound intensity level as the main parameter. The sound intensity level was assessed by the height of the recorded peak. An effort was made to select compositions with low sensitivity in accordance with the safety requirements. The selected compositions are presented in Table 4.

Table 4. Selected pyrotechnic compositions producing the best acoustic effect.

\begin{tabular}{|c|c|c|c|c|c|}
\hline \multirow{2}{*}{$\begin{array}{c}\text { Type of } \\
\text { Composition }\end{array}$} & \multirow{2}{*}{ Designation } & \multicolumn{4}{|c|}{ Content of Individual Components (\%) } \\
\hline & & $\mathrm{KClO}_{4}$ & $\mathrm{Fe}_{2} \mathrm{O}_{3}$ & Al & $\mathrm{S}$ \\
\hline \multirow{3}{*}{ M-1 } & $1 \mathrm{~B}$ & 42 & 13 & 30 & 15 \\
\hline & $2 \mathrm{~B}$ & 36 & 17 & 22 & 25 \\
\hline & & $\mathrm{KClO}_{4}$ & $\mathrm{Fe}_{2} \mathrm{O}_{3}$ & PAM & $S$ \\
\hline \multirow{3}{*}{ M-2 } & $4 \mathrm{~B}$ & 35 & 18 & 27 & 20 \\
\hline & $5 C$ & 38 & 15 & 22 & 25 \\
\hline & $6 \mathrm{~A}$ & 30 & 20 & 20 & 30 \\
\hline
\end{tabular}

\section{Test of the Safety and Performance Properties of Pyrotechnic Compositions}

Knowledge of the performance properties of pyrotechnic compositions is necessary when selecting the manufacturing process. To determine the performance properties of optimum compositions, they were subjected to an extended range of tests, including the Trauzl lead block test, the Koenen friction sensitivity test using the Peters apparatus, the burning rate, the flash fire temperature, and the sound intensity level.

\subsection{Trauzl Lead Block Test}

The Trauzl lead block test consists in measuring the increase in the volume of a hole drilled in a lead block caused by the explosion of $10 \mathrm{~g}$ of composition placed in this hole [17]. The explosive placed in the block is covered with sand and detonated electronically. The result is the arithmetic mean of the two measurements. 


\subsection{Koenen Friction Sensitivity Test Using the Peters Apparatus}

In the technological process, special care is taken to ensure that compositions are not overly sensitive to mechanical stimuli. Therefore, for safety reasons, the pyrotechnic compositions were tested for friction sensitivity.

The Koenen friction sensitivity test using the Peters apparatus (Figure 1) [18] involves the determination of the lowest punch pressure in kilograms at which deflagration, flash fire, etc., occur in 6 tests. Measurements are taken by placing the tested material (in a specified small amount) on a porcelain plate with grooves and applying an appropriate load to the apparatus arm [19].

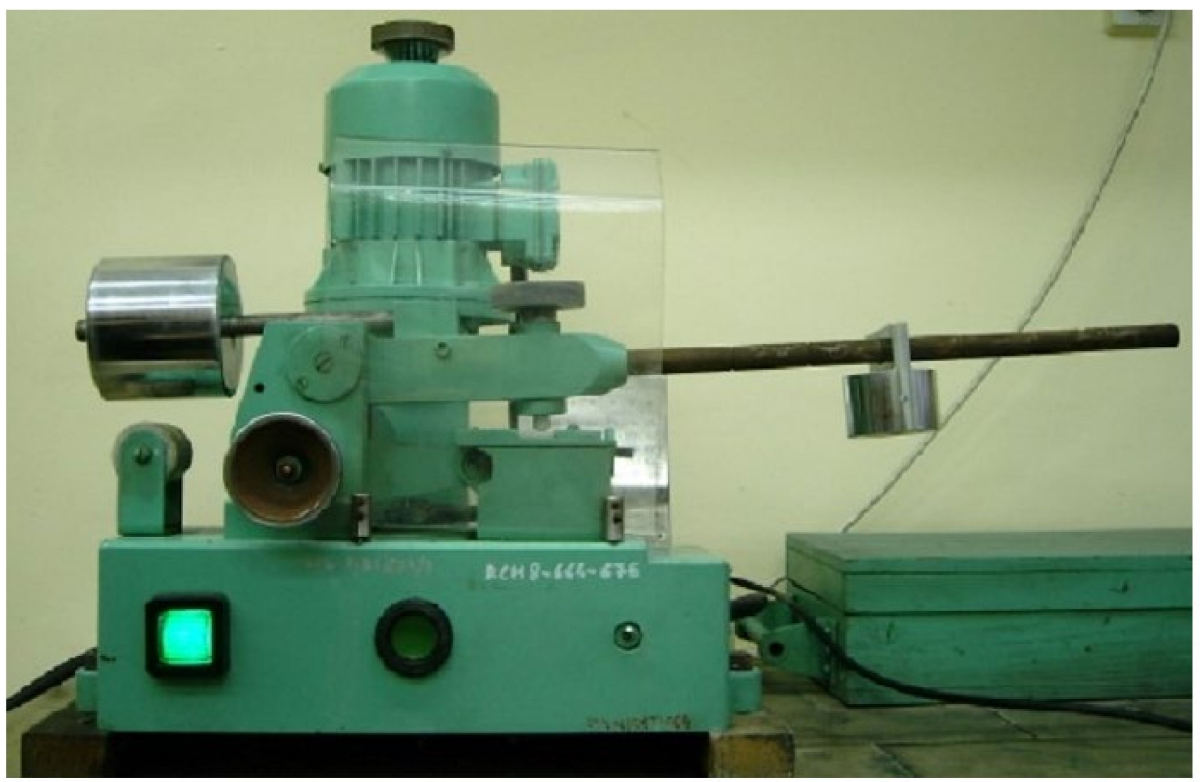

Figure 1. Apparatus for testing sensitivity to friction (Peters apparatus) [20].

\subsection{Burning Rate}

An important parameter affecting the performance of the product is the burning rate of the composition (the higher it is inside the firecracker casing, the more beneficial the effect). Therefore, for the sake of quality, burning rate tests were conducted, and the mean rate was determined.

Appropriate weighted amounts of pyrotechnic compositions were placed in pipes (PVC, LG type, dimensions $\varnothing_{\text {ext }} / \varnothing_{\text {int }} 6.0 / 5.8 \mathrm{~mm}$ ) with a flame retardant bed containing $40 \%$ antimony, $40 \%$ colcothar, and $20 \%$ potassium chlorate (VII). The tested pyrotechnic compositions were ignited by a Class $0.2 \mathrm{~A}$ fuse head. Time measurements were taken using a stopwatch with an accuracy of $0.5 \mathrm{~s}$. The length of the measurement section was $200 \mathrm{~mm}$. The result was an arithmetic mean of three measurements expressed in centimeters per second [19].

\subsection{Flash Fire Temperature}

Testing the flash fire (decomposition) temperature [21] involves heating the test sample in specific conditions at a rate of $278 \mathrm{~K}$ per minute starting from $373 \mathrm{~K}$ and reading the temperature at which the decomposition occurred. A contact thermometer is used to read the decomposition temperature. The lowest temperature out of the three temperatures at which the decomposition occurred during the three tests is taken as the decomposition temperature. The decomposition type is also described: gradual decomposition, sudden combustion, etc. 


\subsection{Sound Intensity Level}

A loop oscillograph (type 9 S0-1 F2) was used to measure the sound intensity level. Pyrotechnic compositions containing appropriately selected components were placed in the firecracker casing (ZT-1), with the fuse unit being adapted to the measurement methodology. The fuse was a head (head resistance 1.9-2.1 $\Omega$.) with an igniter attached to it. The igniter was attached to the head with adhesive tape. This fuse unit was placed inside the firecracker body and then electrically stimulated with a 0.6 A current. The ZT- 1 firecracker body is shown in Figure 2.

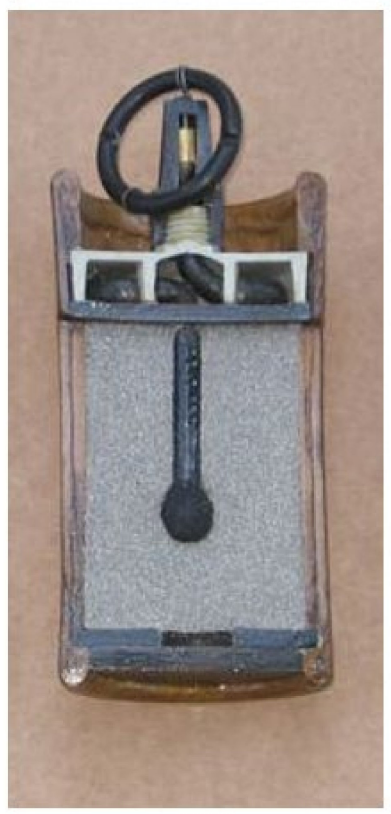

(a)

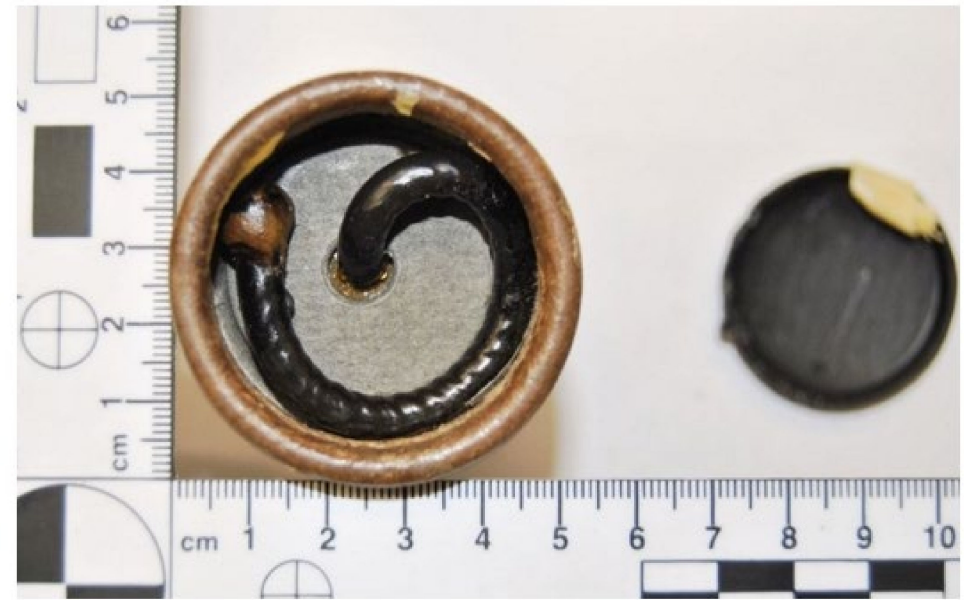

(b)

Figure 2. Illustrative view of the ZT-1 firecracker body; (a) cross-section view and (b) top view [22,23].

The sound intensity level was recorded with an acoustic receiver. The receiver was a $10 \mathrm{~W}$ loudspeaker. The loudspeaker was placed inside a non-airtight steel casing $2 \mathrm{~m}$ away from the place of firecracker ignition. The loudspeaker generated specific electromotive force, which was proportional to the sound intensity level of the firecracker explosion. The electromotive force initiated the oscillograph measurement loop (internal resistance $1.6 \Omega$; sensitivity $0.85 \mathrm{~mm} / \mathrm{mA}$ ), simultaneously causing the recording paper to be lit. The recording paper moved at a rate of $2 \mathrm{~m} / \mathrm{s}(1 \mathrm{~mm}-0.5 \mathrm{~m} / \mathrm{s})$.

Loop oscillation was eliminated by removing one oscillation side with a rectifier system. Curves represented the sound intensity level. The maximum value of the curves was measured, with the result being the mean of the two peak height measurements. Damping (with a $250 \mu \mathrm{F}$ condenser) was used for final tests, as a result of which sensitivity in a ratio of 1:3 compared to the previous sensitivity value was obtained. Damping was necessary as the peak value of the strongest compositions was larger than the recording paper (it exceeded the paper size).

The test results are given in Table 5, while the graphical presentation of the sound intensity level is shown in Figures 3-10. 
Table 5. Explosive properties of optimum compositions.

\begin{tabular}{|c|c|c|c|c|c|c|}
\hline $\begin{array}{c}\text { Type of } \\
\text { Composition }\end{array}$ & Designation & $\begin{array}{c}\text { Trauzl Block } \\
\text { Volume Increase } \\
(\mathrm{mL})\end{array}$ & $\begin{array}{c}\text { Friction } \\
\text { Sensitivity-Pressure } \\
(\mathbf{k g})\end{array}$ & $\begin{array}{l}\text { Mean Burning } \\
\text { Rate }(\mathrm{cm} / \mathrm{s})\end{array}$ & $\begin{array}{l}\text { Decomposition } \\
\text { (Flash Fire) } \\
\text { Temperature (K) }\end{array}$ & $\begin{array}{c}\text { Sound Intensity } \\
\text { Level (Maximum } \\
\text { Peak Height) } \\
(\mathrm{mm} / \mathrm{dB})\end{array}$ \\
\hline M-0 reference & M-0 & 109 & 12.8 & 0.29 & $\begin{array}{l}453 \text { yellow thin } \\
\text { layer }\end{array}$ & $57 / 117$ \\
\hline \multirow{4}{*}{ M-1 } & $1 \mathrm{~B}$ & 104 & 4.8 & 0.35 & $\begin{array}{l}493 \text { yellow thin } \\
\text { layer }\end{array}$ & $79 / 123.5$ \\
\hline & $1^{\prime} B^{*}$ & 193 & 6.0 & 0.41 & $\begin{array}{l}473 \text { yellow thin } \\
\text { layer }\end{array}$ & $35.5 / 110$ \\
\hline & $2 B$ & 100 & 8.0 & 0.34 & - & $44 / 112.5$ \\
\hline & $2^{\prime} \mathrm{B}^{* *}$ & 124 & 7.2 & 0.31 & - & $56.5 / 116.5$ \\
\hline \multirow{3}{*}{ M-2 } & $4 \mathrm{~B}$ & 100 & 3.2 & 0.93 & $\begin{array}{l}503 \text { yellow thin } \\
\text { layer }\end{array}$ & $82 / 124.5$ \\
\hline & $5 \mathrm{C}$ & 122 & 2.8 & 0.44 & $\begin{array}{l}498 \text { yellow thin } \\
\text { layer }\end{array}$ & $100 / 130$ \\
\hline & $6 \mathrm{~A}$ & 105 & 7.2 & 0.39 & - & $36.5 / 110$ \\
\hline
\end{tabular}

* $1^{\prime}$ B-pyrotechnic composition containing flake aluminum (replacing aluminum powder). ${ }^{* *}{ }^{\prime}$ B-pyrotechnic composition containing flake aluminum (replacing aluminum powder). The M-1 compositions have the lowest friction sensitivity, while the M-2 compositions have the highest burning rate. The thermal resistance of the tested compositions is high; no flash fire is observed, only a yellow thin layer is formed as a result of sulfur emission. The decomposition temperature results are not complete due to the labor-intensive research method, but they make it possible to evaluate this parameter in individual groups. The size of the bulge in the Trauzl Block indicates the "strength" of the pyrotechnic material. Obtaining a high numerical value proves the higher energetic potential of the pyrotechnic material. Most of the pyrotechnic mixtures are characterized by similar values of this parameter to the "reference composition" M- 0 . In the case of 1 'B (containing aluminum flake), the volume increase was almost twice as high: $193 \mathrm{~mL}$. Higher values of the parameter were obtained for 2'B, also with aluminum flake, $(124 \mathrm{~mL})$ and for the composition 5C (122 mL). The sound intensity level (the mean of two measurements) expressed by the peak height is larger than the value determined for the reference composition for compositions $1 \mathrm{~B}$ (from the M-1 group) and compositions $4 \mathrm{~B}$ and $5 \mathrm{C}$ from the $\mathrm{M}-2$ group.

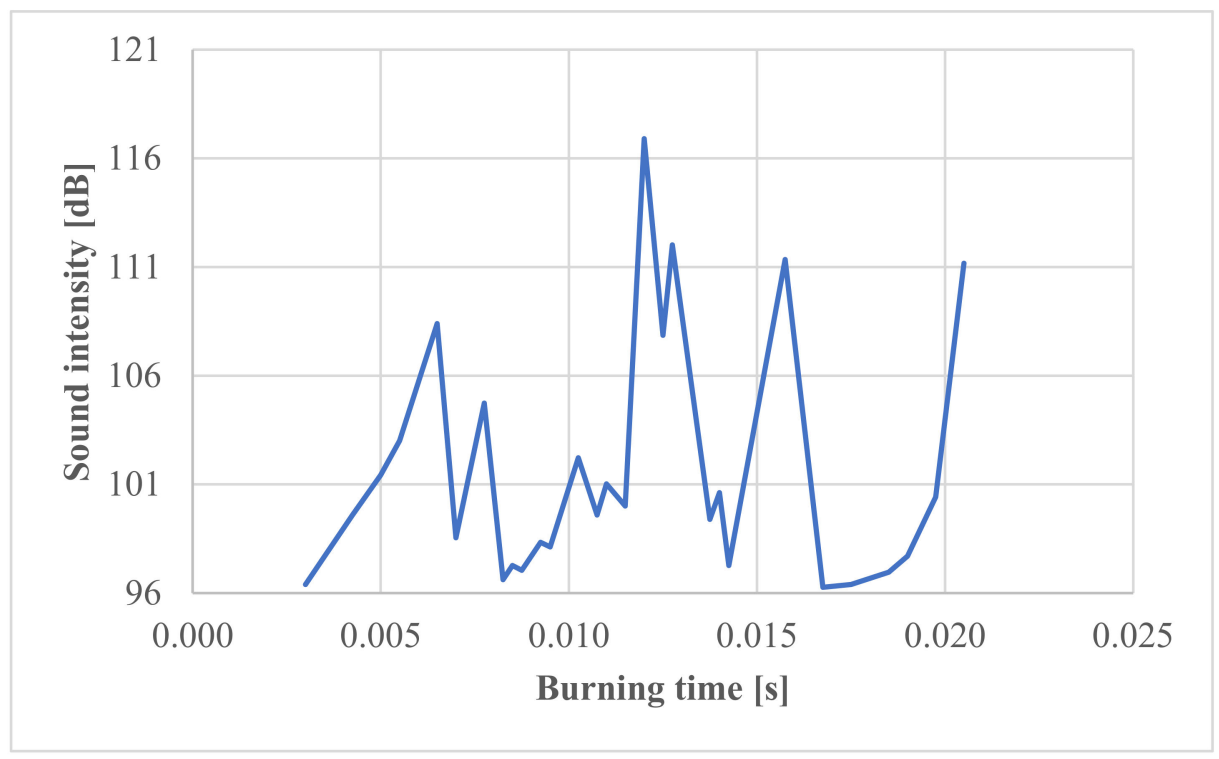

Figure 3. Graphical presentation of the sound intensity level for composition M-0. 


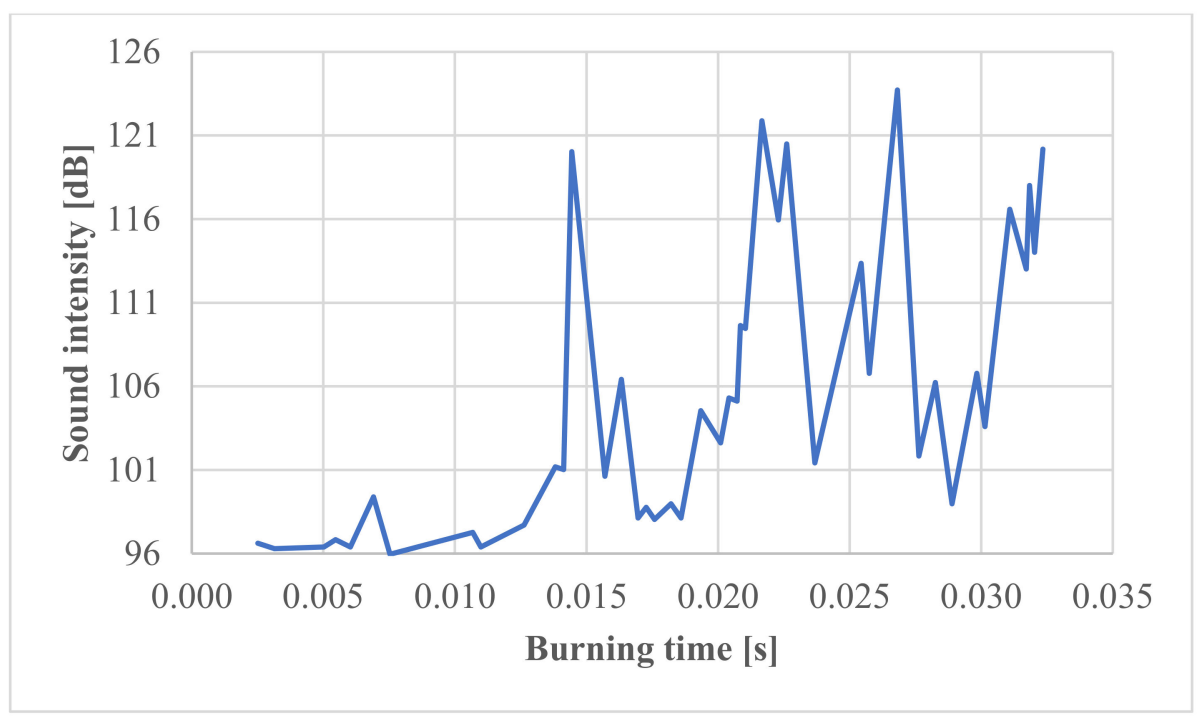

Figure 4. Graphical presentation of the sound intensity level for composition M-1-1B.

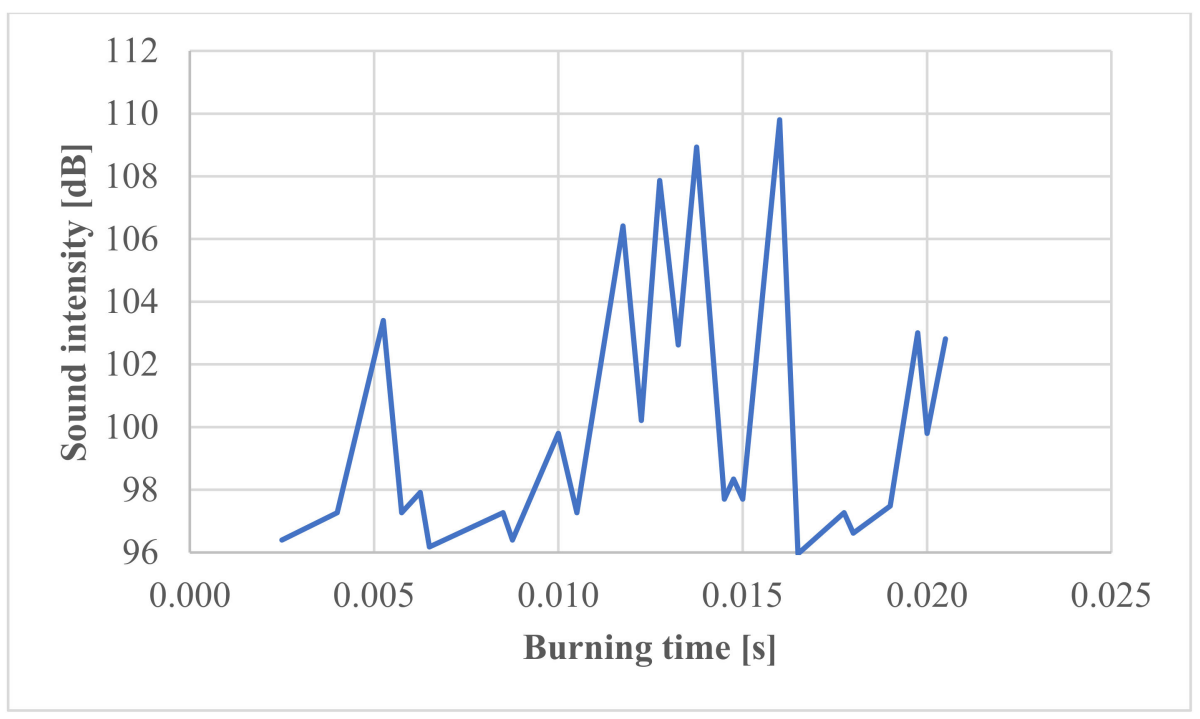

Figure 5. Graphical presentation of the sound intensity level for composition M-1-1’B.

For the sake of a thorough evaluation of explosive properties, the table includes the data for the reference composition.

The conducted tests also included a test with the powder

Al for the M- 1 composition. By using the flake Al content of $30 \%$ and $22 \%$ for composition $1^{\prime} \mathrm{B}$ and $2^{\prime} \mathrm{B}$, respectively, compositions analogous to $1 \mathrm{~B}$ and $2 \mathrm{~B}$ were obtained. The flake $\mathrm{Al}$ reduced the friction sensitivity of composition 1 'B and adversely affected the sound intensity level. 


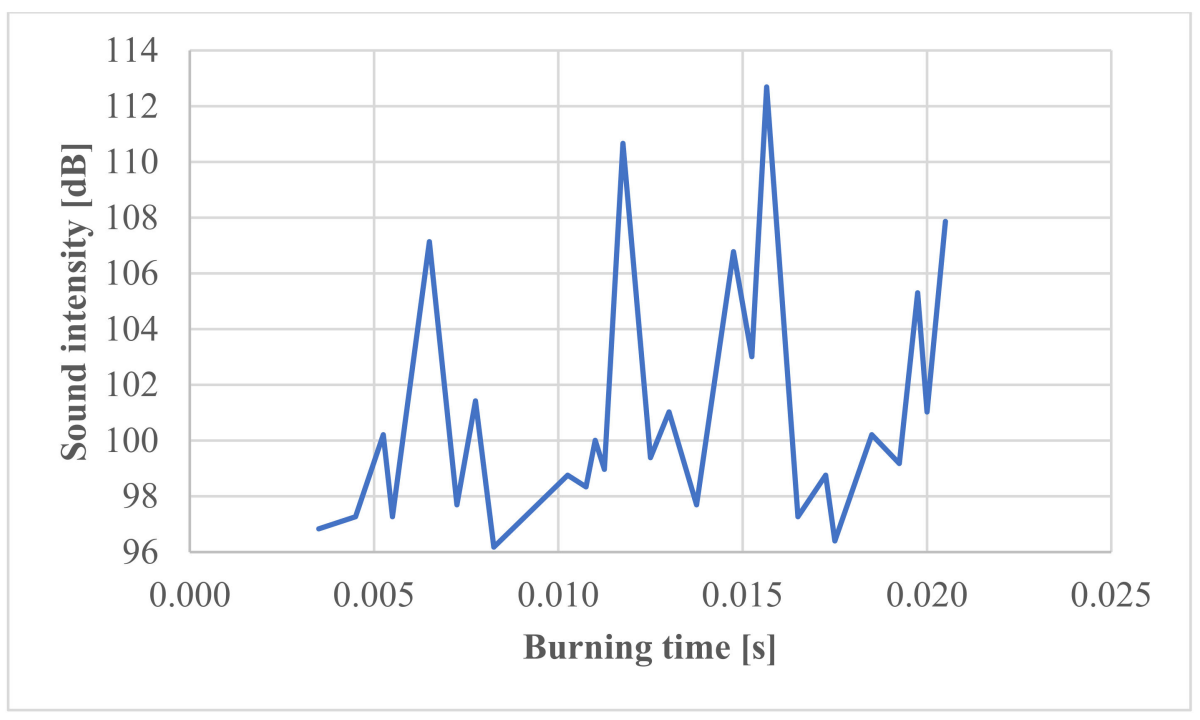

Figure 6. Graphical presentation of the sound intensity level for composition M-1-2B.

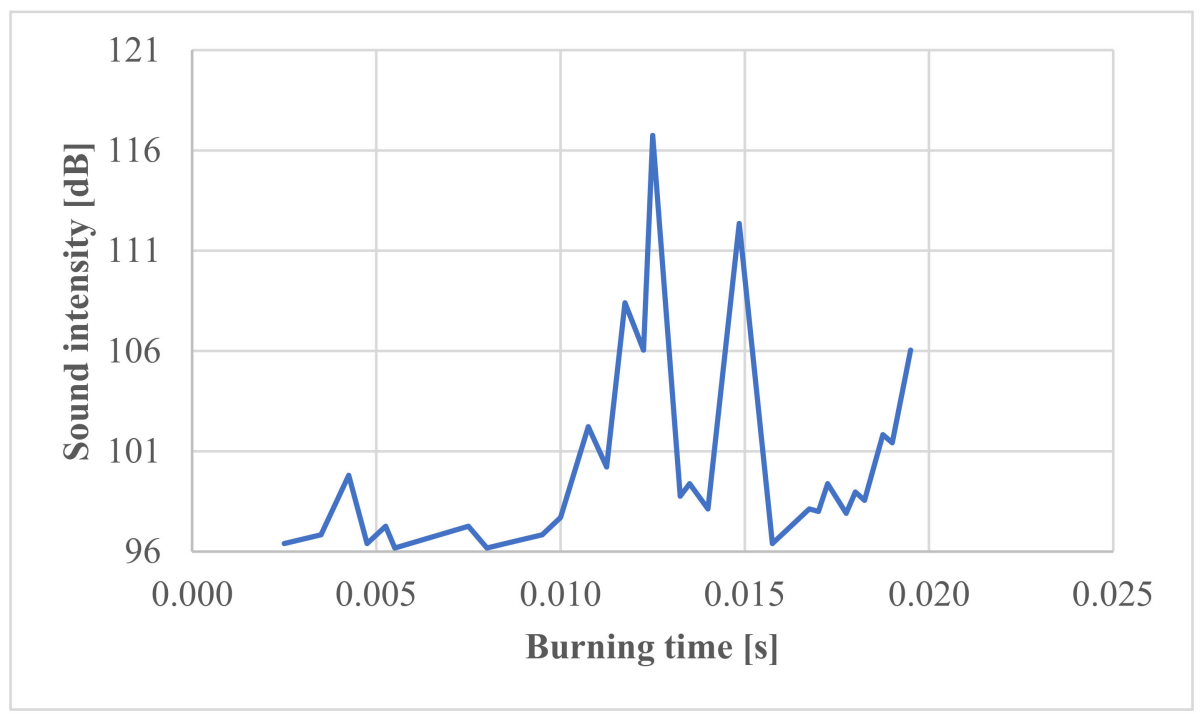

Figure 7. Graphical presentation of the sound intensity level for composition M-1-2'B.

In the case of composition $2^{\prime} \mathrm{B}$, the performance of the firecracker improved but its friction sensitivity increased. The lower bulk density of the flake compared to aluminum powder meant that only $73 \%$ and $78 \%$ of the firecracker casing intended to hold $100 \mathrm{~g}$ of the composition was filled for composition $1^{\prime} \mathrm{B}$ and $2^{\prime} \mathrm{B}$, respectively.

To evaluate the effect of certain thermodynamic values on explosive combustion parameters, calculations were made based on complete combustion equations. The values obtained are given in Table 6. Thermodynamic calculations were performed with the ITC Thermodynamic Code computer program. 


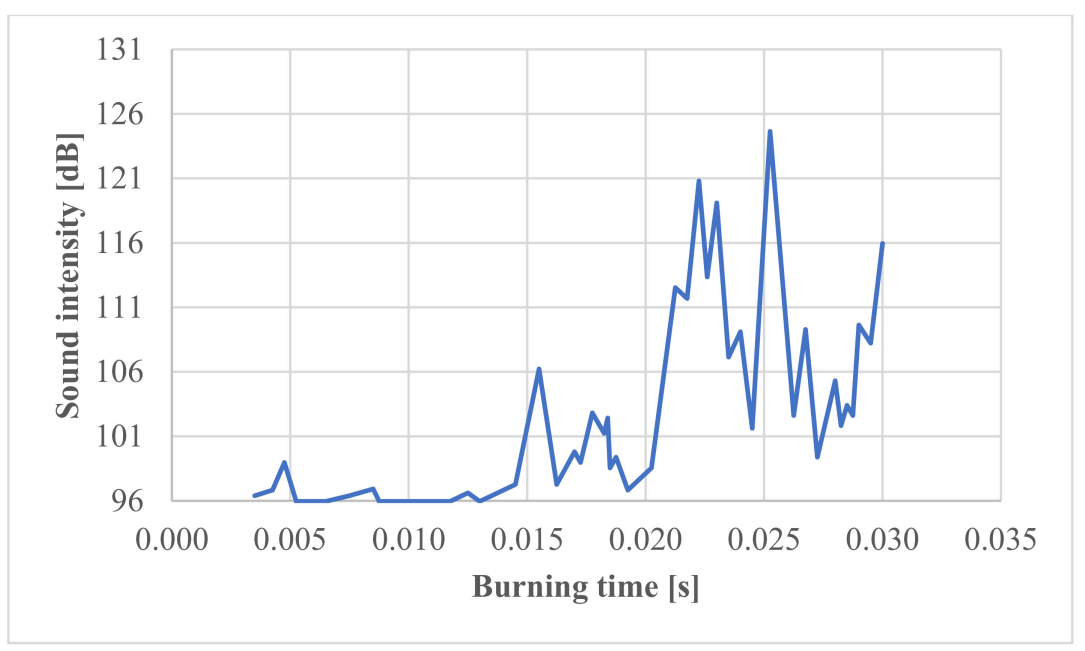

Figure 8. Graphical presentation of the sound intensity level for composition M-2-4B.

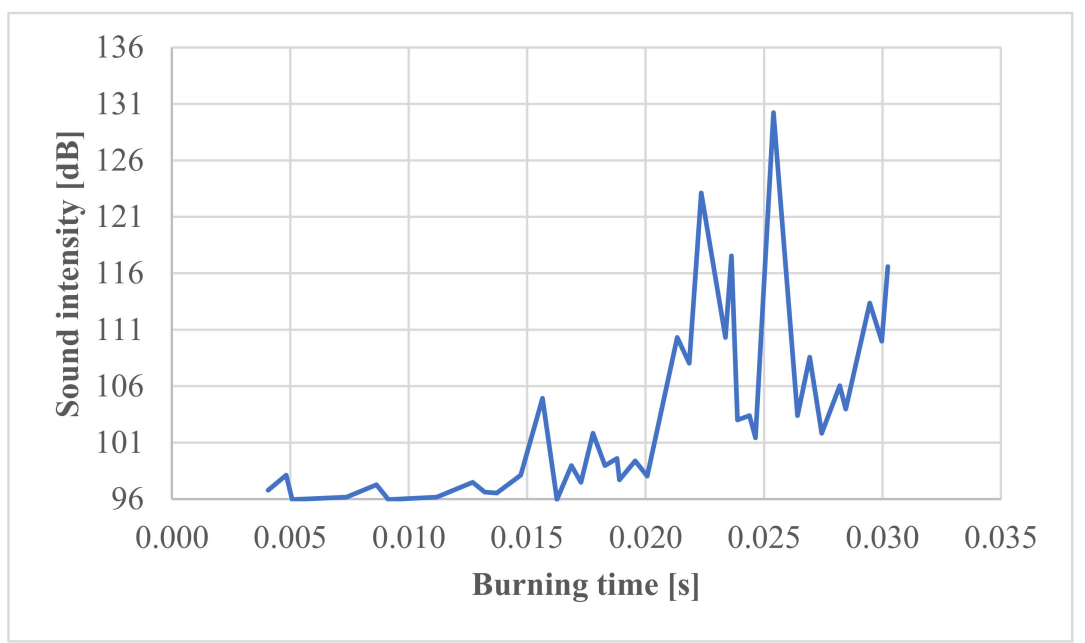

Figure 9. Graphical presentation of the sound intensity level for composition M-2-5C.

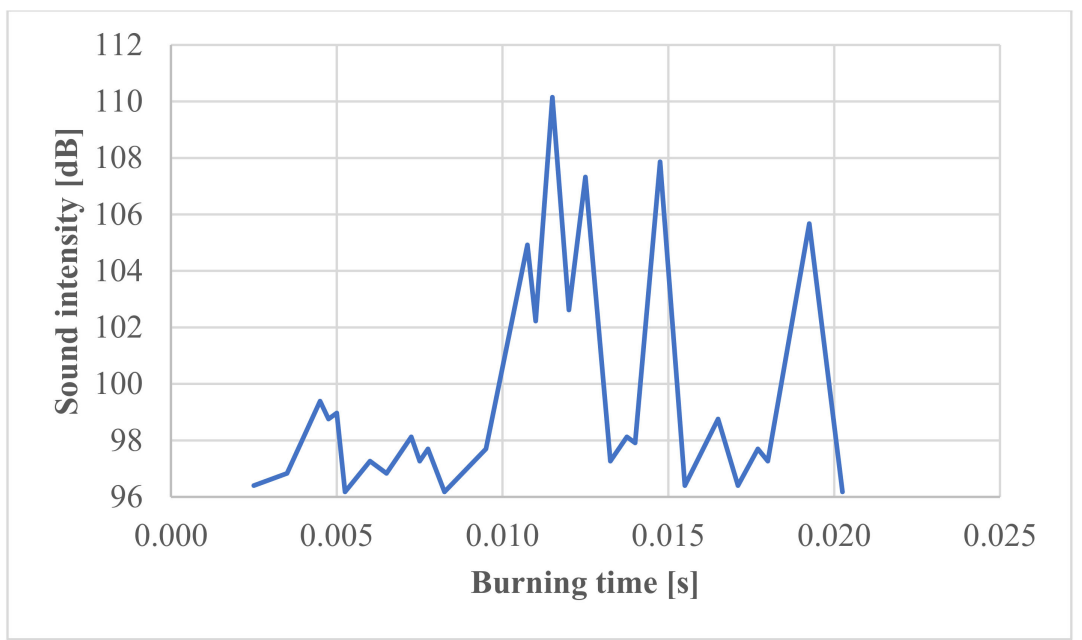

Figure 10. Graphical presentation of the sound intensity level for composition M-2-6A. 
Table 6. Thermodynamic values of products of combustion of optimum compositions.

\begin{tabular}{|c|c|c|c|c|c|c|}
\hline $\begin{array}{c}\text { Type of } \\
\text { Composition }\end{array}$ & Designation & $\begin{array}{c}\text { Oxygen Balance } \\
\text { OB (\%)* }\end{array}$ & $\begin{array}{c}\text { Explosive } \\
\text { Combustion } \\
\text { Heat } \\
\text { Qw (kJ/kg)** }\end{array}$ & $\begin{array}{c}\text { Explosive } \\
\text { Combustion } \\
\text { Temperature } \\
\text { (K) } * * *\end{array}$ & $\begin{array}{c}\text { Specific Volume } \\
\text { of Combustion } \\
\text { Products } \\
\mathrm{V}_{\mathrm{o}}\left(\mathrm{dm}^{3} / \mathrm{kg}\right) * * * *\end{array}$ & $\begin{array}{c}\text { Explosive } \\
\text { Combustion } \\
\text { Pressure } \\
\mathrm{P}(\mathrm{MPa}) * * * * *\end{array}$ \\
\hline M-0 reference & M-0 & -12.4 & 5646.7 & 634 & 181 & 42.5 \\
\hline \multirow{4}{*}{ M-1 } & 1B & -18.4 & 8276.8 & 940 & 105 & 36.6 \\
\hline & $1^{\prime} \mathrm{B}$ & -16.5 & 7336.8 & 892 & 118.3 & 39.2 \\
\hline & $2 B$ & -22.9 & 6770.9 & 800 & 175 & 52 \\
\hline & $2^{\prime} \mathrm{B}$ & -20.1 & 6042.1 & 792 & 177.2 & 52.1 \\
\hline \multirow{3}{*}{ M-2 } & $4 \mathrm{~B}$ & -19.5 & 7057.2 & 714 & 140 & 37.1 \\
\hline & $5 \mathrm{C}$ & -20.1 & 6149.7 & 679 & 175 & 44.1 \\
\hline & $6 \mathrm{~A}$ & -25.7 & 6124.7 & 667 & 210 & 52 \\
\hline
\end{tabular}

* Oxygen balance- the amount of oxygen in the structure of the pyrotechnic composition informing about the amount of oxygen needed to oxidize all combustible components it contains. ${ }^{* *}$ Explosive combustion heatthe amount of energy released during the chemical reaction of the combustion of a pyrotechnic composition. *** Explosive combustion temperature-the maximum value of the temperature of the gaseous products of the combustion reaction. ${ }^{* * * *}$ Specific volume of combustion products-the volume of gaseous products of the combustion reaction of the pyrotechnic composition. ${ }^{* * * * *}$ Explosive combustion pressure-the value of the pressure generated by gaseous products resulting from the combustion process. It can be observed that the oxygen balance of optimum compositions is similar to that of the reference composition (similar values). The high combustion heat value of the compositions has a certain effect on the sound effect.

\section{Physicochemical Tests}

It is common knowledge that substances can undergo certain physical and chemical changes during their storage. The same applies to pyrotechnic compositions. These changes are important because they adversely affect the product quality and often render a composition dangerous. Physicochemical tests facilitate the determination of conditions and the period of storage of products containing pyrotechnic compositions.

To check if the compositions undergo certain changes, their stability was determined by:

- $\quad$ Storage at $348 \mathrm{~K}$.

- $\quad$ Exothermic decomposition using differential thermal analysis (DTA).

\subsection{Determination of Stability during Storage at $348 \mathrm{~K}$}

Testing the stability of compositions by storing them at $348 \mathrm{~K}$ involves [24] the determination of a loss in sample weight during 48 -h storage.

A weighed-out sample of the tested substance $(10 \mathrm{~g})$ is placed in a drier at a temperature of approx. $348 \mathrm{~K}$ and dried for $24 \mathrm{~h}$. After $24 \mathrm{~h}$, the sample is weighed and then replaced in the drier. After another 24-h storage, the sample is weighed and the weight loss is calculated for both 24-h periods. The arithmetic mean of both tests is also calculated. The samples are weighed in a closed weighing bottle and dried in an open weighing bottle.

The weight loss is calculated using the following formulas:

$X_{24}^{\prime}=\frac{G_{2}-G_{3}}{G_{2}-G_{1}}$ loss of weight of the tested sample after the first 24-h period of storage at $348 \mathrm{~K}$,

$X_{24}^{\prime \prime}=\frac{G_{3}-G_{4}}{G_{2}-G_{1}}$ loss of weight of the tested sample after another 24 -h period of storage at $348 \mathrm{~K}$, and

$X_{48}=X_{24}^{\prime}+X_{24}^{\prime \prime}$ loss of weight of the tested sample after 48 -h storage at $348 \mathrm{~K}$,

where

$\mathrm{G}_{1}$ is the weight of an empty weighing bottle $(\mathrm{g})$,

$\mathrm{G}_{2}$ is the weight of the weighing bottle with the tested composition inside (g), 
$\mathrm{G}_{3}$ is the weight of the weighing bottle containing tested composition after 24-h storage (g), and

$\mathrm{G}_{4}$ is the weight of the weighing bottle containing tested composition after $48-\mathrm{h}$ storage (g).

The weight loss values are presented in Table 7.

Table 7. Changes in the weight of pyrotechnic compositions evaluated with the dryer method.

\begin{tabular}{|c|c|c|c|c|}
\hline $\begin{array}{c}\text { Type of } \\
\text { Composition }\end{array}$ & Designation & $\begin{array}{c}\text { Weight Loss } \\
\text { after } 24-h \\
\text { Storage } X_{24}^{\prime}(\%)\end{array}$ & $\begin{array}{l}\text { Weight Loss } \\
\text { after Another } \\
24-\mathrm{h} \text { Storage } \\
X^{\prime \prime}{ }_{24}(\%)\end{array}$ & $\begin{array}{l}\text { Weight Loss } \\
\text { after } 48-\mathrm{h} \\
\text { Storage } \mathrm{X}_{48}(\%)\end{array}$ \\
\hline M-0 reference & M-0 & 0.05 & 0.01 & 0.06 \\
\hline \multirow{4}{*}{ M-1 } & $1 \mathrm{~B}$ & 0.12 & 0.02 & 0.14 \\
\hline & $1^{\prime} B$ & 0.24 & 0.01 & 0.25 \\
\hline & $2 B$ & 0.12 & 0.04 & 0.16 \\
\hline & $2^{\prime} \mathrm{B}$ & 0.17 & 0.1 & 0.27 \\
\hline \multirow{3}{*}{ M-2 } & $4 \mathrm{~B}$ & 0.12 & 0 & 0.12 \\
\hline & $5 C$ & 0.11 & 0 & 0.11 \\
\hline & $6 \mathrm{~A}$ & 0.16 & 0 & 0.16 \\
\hline
\end{tabular}

For the sake of comparability, the values obtained for the reference composition are also included. The weight loss is expressed as a percentage.

The tests reveal that the weight loss is small (similar) for individual groups, amounting to $\sim 0.2 \%$. The only compositions with a higher weight loss $(\sim 0.3 \%)$ are those containing flake aluminum; however, it does not significantly affect stability. Based on the results of the dryer method, it can be concluded that the optimum compositions are stable.

\subsection{Determination of Stability Using Differential Thermal Analysis (DTA)}

The test of stability of pyrotechnic compositions by differential thermal analysis (DTA) [25] consists in determining the temperature at which the exothermic decomposition of the test sample is recognized. The tested sample is placed in conditions where the temperature is raised at a precisely defined rate with simultaneous recording of the temperature of the environment and the temperature differences between the test environment and the tested sample. The decomposition temperature is read off the graph obtained.

Normally, for this type of analysis, $\mathrm{NH}_{4} \mathrm{ClO}_{4}$ is used as it has a characteristic temperature at which its properties change.

A test concerning exothermic decomposition was carried out on a group-by-group basis taking into consideration flash fire temperature. The reason for this was the fact that the apparatus might be programmed to generate heat of a specific temperature and thus protect against possible damage.

The temperature was determined by assuming the following values for compositions $\mathrm{M}-1$ and $\mathrm{M}-2: \mathrm{T}_{\mathrm{o}}=291 \mathrm{~K}$ and $\mathrm{T}_{\mathrm{u}}=548 \mathrm{~K}$.

The tests were carried out on the RAT-I Analyser, and the results obtained are presented in the form of graphs (Figures 11 and 12). The figures contain curves showing the thermostability of the compositions. 


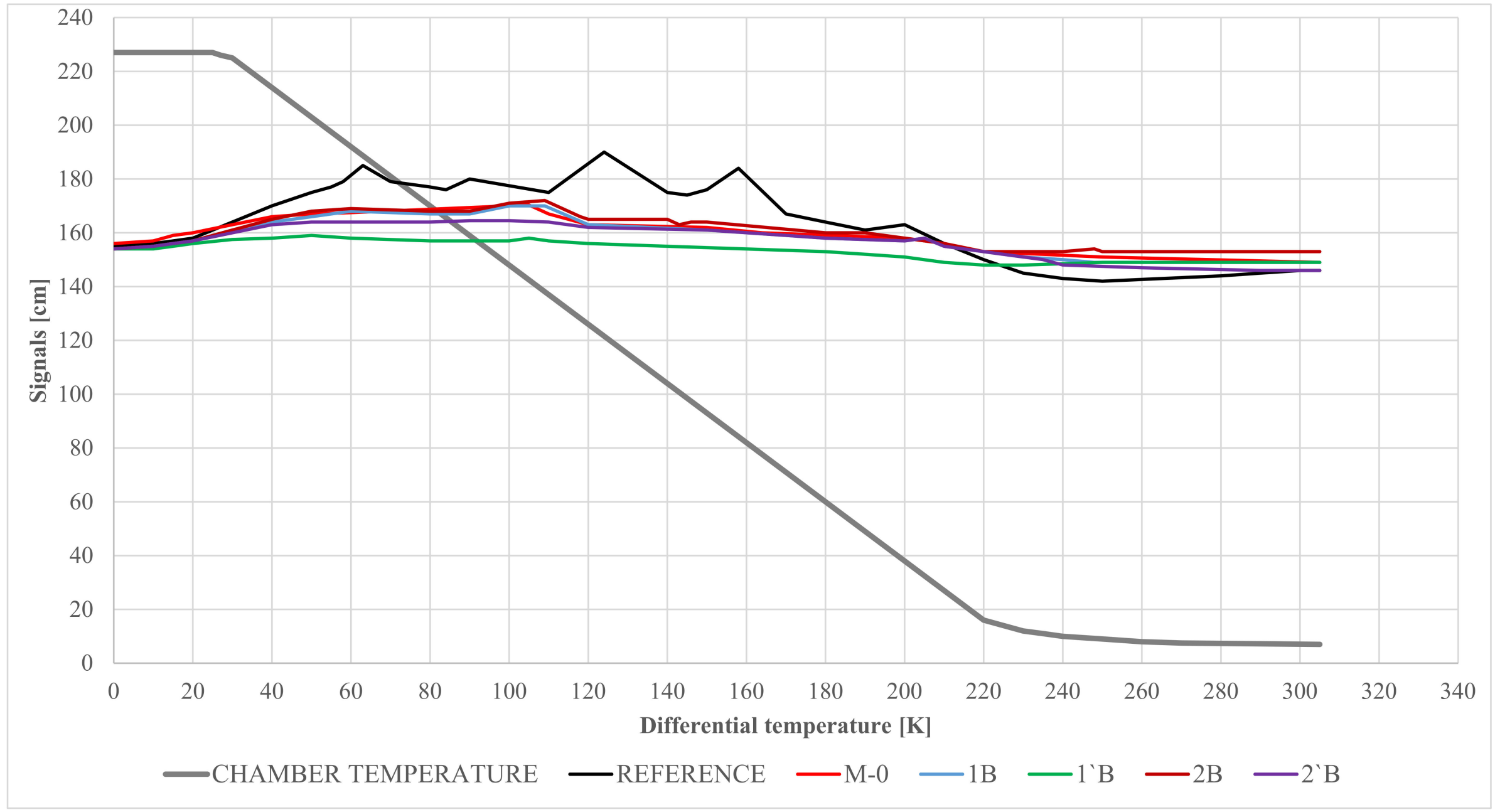

Figure 11. Curves showing the thermostability of the compositions from the $\mathrm{M}-1$ group: reference-black line, chamber temperature-gray line, $\mathrm{M}-0$ reference composition—red line, $1 \mathrm{~B}$-blue line, $\mathrm{1}^{\prime} \mathrm{B}$ - green line, $2 \mathrm{~B}$ - brown line, and $2^{\prime} \mathrm{B}$-purple line. 


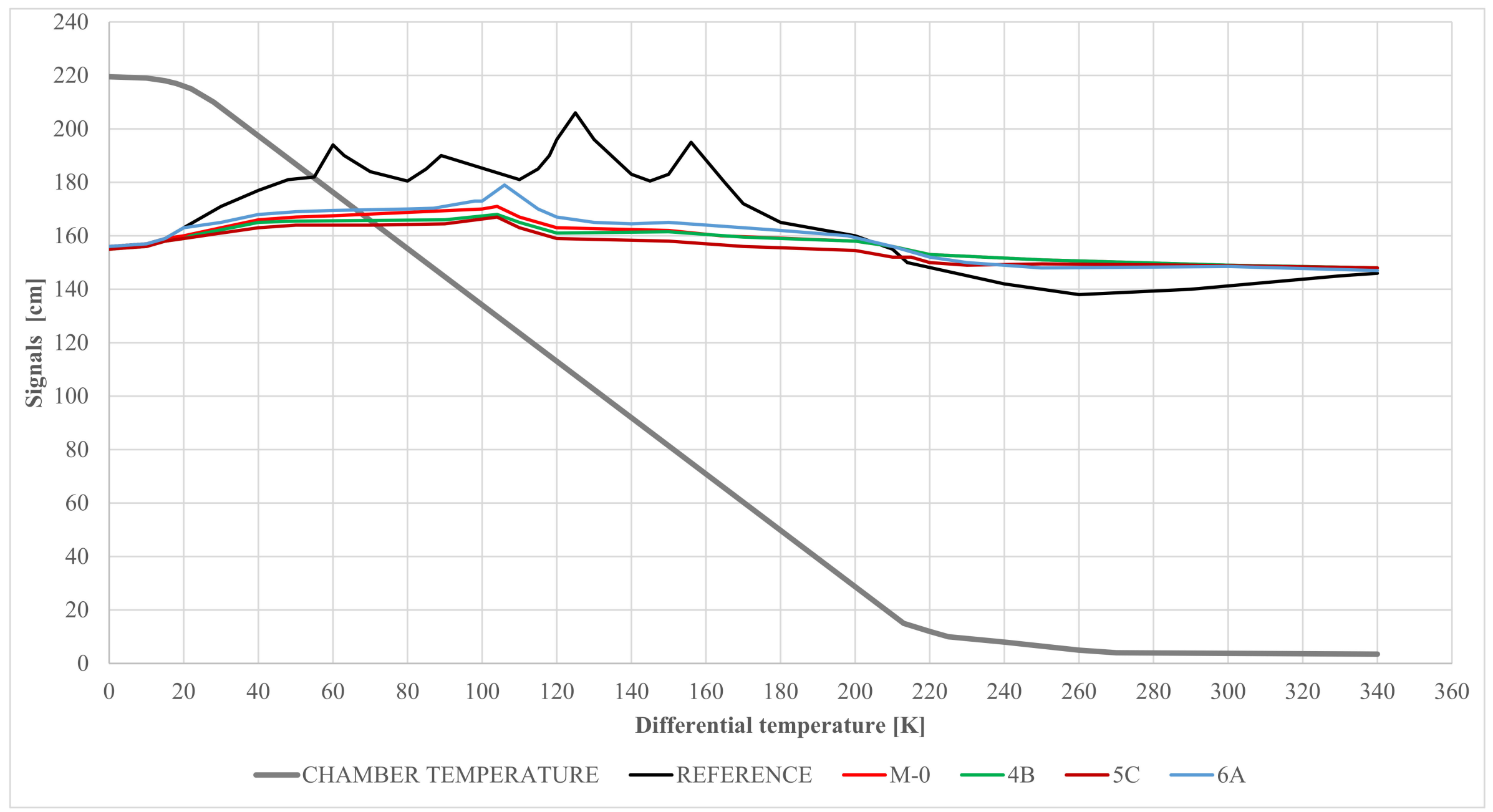

Figure 12. Curves showing the thermostability of the compositions from the M-2 group: reference-black line, chamber temperature-gray line, M- 0 reference composition—red line, 4B-green line, 5C—brown line, and 6A—blue line. 
The black line was adopted for ammonium nitrate and the red line for the M- 0 composition. The temperature in the individual figures is indicated by a solid line.

Analyzing the curves, one should state that no abrupt changes have been spotted. The lines representing individual compositions run in close proximity to each other-they almost overlap. One might see a slight deviation from a constant level, which may result from phase transitions of sulfur.

The differential thermal analysis method and the drying method prove the thermostability of the compositions. This is also consistent with the flash fire temperature.

\section{Summary}

The article presents the results of tests of explosive and physicochemical properties of pyrotechnic compositions used to produce an acoustic effect depending on their content.

So far, the evaluation of the reliability has been based only on organoleptic testing (by hearing). Instrumental research methods were used to assess the acoustic effect.

A graphical representation (picture) of the occurring phenomenon was obtained, and the quality of the composition was evaluated based on the height of the maximum peak (Figures 1-9). The obtained value was compared with a reference composition. This study was vital taking into account the requirement of composition to produce a suitable acoustic effect.

The aim of the research was to find out the "strength" of the pyrotechnic compositions and thus to assess their ability to produce sound at the appropriate frequency and intensity. The following measurements were carried out to test the explosive properties:

- $\quad$ Friction sensitivity - which indicates the sensitivity of the compositions and makes it possible to establish safety requirements concerning the manufacturing process.

- $\quad$ Strength of explosive properties of compositions - which is vital for safety reasons.

- Burning rate-which involves the assessment of the dynamics of the combustion process and the influence of this phenomenon on the effect of simulating an explosion.

- $\quad$ Flash fire temperature-which facilitates the assessment of the ability of compositions to undergo thermal decomposition.

Tests for physicochemical properties, stability determination at storage at $348 \mathrm{~K}$, and stability determination using differential thermal analysis (DTA) were carried out. These methods indicated the thermostability of the compositions and allowed establishing the safety requirements concerning their storage.

\section{Conclusions}

1. The measured values of the sound intensity level for individual pyrotechnic compositions from groups $\mathrm{M}-1$ and $\mathrm{M}-2$ are similar to the values obtained for the reference composition $\mathrm{M}-0$. In the case of pyrotechnic compositions $1 \mathrm{~B}$ (from the M-2 group) as well as $4 \mathrm{~B}$ and $5 \mathrm{C}$ (from the M-2 group), higher values were registered.

2. The studied pyrotechnic compositions are characterized by oxygen balance, specific volume of combustion products, and explosive combustion pressure similar to those of the reference M-0 composition. All pyrotechnic compositions from groups $\mathrm{M}-1$ and M-2 show higher explosive combustion heat and explosive combustion temperature than the reference $\mathrm{M}-0$ composition.

3. It was found that $\mathrm{Fe}_{2} \mathrm{O}_{3}$ can be used as an oxidant in combination with $\mathrm{KClO}_{4}$ and sulfur can be added in larger amounts than aluminum-magnesium powder (PAM) or aluminum powder (financial importance).

Author Contributions: Conceptualization, J.B.; Formal analysis, K.B.; Methodology, J.B.; Writingoriginal draft, K.B.; Writing-review \& editing, J.B. All authors have read and agreed to the published version of the manuscript.

Funding: This research received no external funding.

Institutional Review Board Statement: Not applicable. 
Informed Consent Statement: Not applicable.

Data Availability Statement: The data presented in this study are available on request from the corresponding author (K.B.).

Conflicts of Interest: The authors declare no conflict of interest.

\section{References}

1. Szydłowski, A. Podstawy Pirotechniki. (Basics of Pyrotechnics); Wydawnictwo MON: Warsaw, Poland, 1957.

2. Conkling, J.A. Chemistry of Pyrotechnics—Basic Principles and Theory; CRC Press: New York, NY, USA, 1985.

3. Kosanke, K.L.; Kosanke, B.J. Pyrotechnic Ignition and Propagation: A Review. J. Pyrotech. 1997, 6, 17-19.

4. Tribelhorn, M.J.; Blenkinsop, M.G.; Brown, M.E. Combustion of Some Iron-Fuelled Binary Pyrotechnic Systems. Thermochim. Acta 1995, 256, 291-307. [CrossRef]

5. Biegańska, J. Ocena szkodliwości ogni sztucznych dla widzów i środowiska (Evaluation of harmfulness of fireworks to humans and environment). Ekol. Tech. 2000, 8, 78-82.

6. Warchoł, R.; Nita, M. Mieszaniny pirotechniczne stosowane w pirotechnicznych układach opóźniających środków bojowych. (Pyrotechnic compositions for use in pyrotechnic delay devices of munitions). Probl. Tech. Uzbroj. 2014, 131, 57-66.

7. Borkowski, J.; Warchoł, R.; Nita, M.; Miszczak, M. Badania procesów spalania mieszanin pirotechnicznych stosowanych w układach opóźniajacych środków bojowych za pomocą rentgenoskopii w czasie rzeczywistym (RTR). (Investigations of burning process of pyrotechnic compositions applied in delay systems of ordnance using Real Time Roentgenoscopy (RTR)). Probl. Tech. Uzbroj. 2015, 44, 79-88.

8. Barański, K. Analysis of the Possibility of Using "Green Pyrotechnics" in the Detonators MW. Ph.D. Thesis, Faculty of Mining and Geoengineering, AGH University of Science and Technology, Cracow, Cracow, Poland, 27 September 2019.

9. $\quad P N-V-04002-2: 1996$; Mieszaniny Pirotechniczne i Wyroby Pirotechniczne. Trwałość Fizyczna i Chemiczna. Oznaczanie Higroskopijności. (Pyrotechnic Mixtures and Pyrotechnic Articles. Physical and Chemical Durability. Determination of Hygroscopicity). Polish Committee for Standardization: Warsaw, Poland, 1996.

10. PN-V-04002-8:1996; Mieszaniny Pirotechniczne i Wyroby Pirotechniczne. Trwałość Fizyczna i Chemiczna. Badania Odporności na Długoletnie Składowanie za Pomoca Zmiennych Cykli Temperaturowych. (Pyrotechnic Mixtures and Pyrotechnic Articles. Physical and Chemical Durability. Research on Resistance to Long-Term Storage by Means of Variable Temperature Cycles). Polish Committee for Standardization: Warsaw, Poland, 1996.

11. PN-V-04002-5:1997; Mieszaniny Pirotechniczne i Wyroby Pirotechniczne. Trwałość Fizyczna i Chemiczna. Oznaczanie Aktywności Glinu. (Pyrotechnic Mixtures and Pyrotechnic Articles. Physical and Chemical Durability. Determination of the Activity of Aluminium). Polish Committee for Standardization: Warsaw, Poland, 1997.

12. PN-V-04002-6:1997; Mieszaniny Pirotechniczne i Wyroby Pirotechniczne. Trwałość Fizyczna i Chemiczna. Oznaczanie Aktywności Magnezu. (Pyrotechnic Mixtures and Pyrotechnic Articles. Physical and Chemical Durability. Determination of the Activity of Magnesium). Polish Committee for Standardization: Warsaw, Poland, 1997.

13. PN-V-04002-7:1997; Mieszaniny Pirotechniczne i Wyroby Pirotechniczne. Trwałość Fizyczna i Chemiczna. Oznaczanie Aktywności Stopów Glinu i Magnezu. (Pyrotechnic Mixtures and Pyrotechnic Articles. Physical and Chemical Durability. Determination of the Activity of Aluminum and Magnesium Alloys). Polish Committee for Standardization: Warsaw, Poland, 1997.

14. Szymańczyk, L.; Maranda, A. Badanie poziomu ciśnienia akustycznego generowanego podczas używania wybranych wyrobów pirotechnicznych widowiskowych (The study of sound pressure level generated by selected fireworks). Materiaty Wysokoenergetyczne/High Energy Materials 2017, 9, 126-135. [CrossRef]

15. Sears, F.W.; Zemansky, M.W. University Physics; Addison-Wesley Publishing Co., Inc.: Reading, MA, USA, 1964.

16. Pawłowska, J. Opracowanie Nowych Składów Mieszanek Pirotechnicznych Pozorujących Odpowiedni Efekt Akustyczny (Development of New Compositions of Pyrotechnic Mixtures Simulating an Appropriate Acoustic Effect). Master's Thesis, Silesian University of Technology, Faculty of Chemical Technology and Engineering, Gliwice, Poland, 1981.

17. PN-C-86037,2000; Materiały Wybuchowe-Oznaczanie Zdolności do Wykonania Pracy w Bloku Ołowianym (ExplosivesDetermination of the Ability to Work in a Lead Block). Polish Committee for Standardization: Warsaw, Poland, 2000.

18. PN-EN 13631-3:2006; Materiały Wybuchowe do Użytku Cywilnego-Materiały Wybuchowe Kruszące-Część 3: Oznaczanie Wrażliwości Materiałów Wybuchowych na Tarcie. (Explosives for Civil Uses-High Explosives-Part 3: Determination of Sensitiveness to Friction of Explosives). Polish Committee for Standardization: Warsaw, Poland, 2006.

19. Biegańska, J.; Barański, K. Experiments with Pyrotechnic Compositions Based on a Mathematical Model-Part I Evaluation of the Applicability of Mathematical Models in Developing Pyrotechnic Compositions Producing an Acoustic Effect. Energies 2021, 14, 8548. [CrossRef]

20. Portal Popularnonaukowy VMC -Zdjęcie Aparatu Petersa. (VMC Popular Science Portal Photo of Peters Apparatus). Available online: http:/ / www.vmc.org.pl/index.php/pirotechnika/pozostae/item/317-metody-bada\%C5\%84-niekt\%C3\%B3rych-w\% C5\%82a\%C5\%9Bciwo\%C5\%9Bci-mw (accessed on 28 December 2021).

21. BN-76/6091-08,1997; Materiały Wybuchowe Górnicze. Oznaczanie Temperatury Rozkładu. (Mining Explosives. Determination of the Decomposition Temperature). Polish Committee for Standardization: Warsaw, Poland, 1997. 
22. Strona Internetowa Zakładu Produkcji Specjalnej "Gamrat" Sp. z o.o., Jasło Katalogi Produktów (The Website of Specjal Production Plant "Gamrat" Ltd., Product Catalogs). Available online: http:/ / www.zpsgamrat.pl/ (accessed on 14 December 2021).

23. Goleniowski, T. Substancje i Przedmioty Niebezpieczne w Naszym Otoczeniu. Część 2. Petarda Wojskowa. (Hazardous Substances and Objects in Our Environment. Part 2. Military Firecracker). Available online: https://www.linkedin.com/pulse/ substancje-i-przedmioty-niebezpieczne-w-naszym-tomasz-goleniowski-1c (accessed on 28 December 2021).

24. PN-EN 13631-2:2004; Materiały Wybuchowe do Użytku Cywilnego-Materiały Kruszące—Część 2: Oznaczanie Stabilności Termicznej Materiałów Wybuchowych (Explosives for Civil Uses-High Explosives-Part 2: Determination of Thermal Stability of Explosives). Polish Committee for Standardization: Warsaw, Poland, 2004.

25. BN-76/6091-41,1976; Materiały Wybuchowe-Oznaczanie Stałości Metoda Rożnicowej Analizy Termicznej. (ExplosivesDetermination of Constancy by Differential Thermal Analysis). Polish Committee for Standardization: Warsaw, Poland, 1976. 